\title{
Muhammadiyah's Manhaj Tarjih: An evolution of a modernist approach to Islamic jurisprudence in Indonesia
}

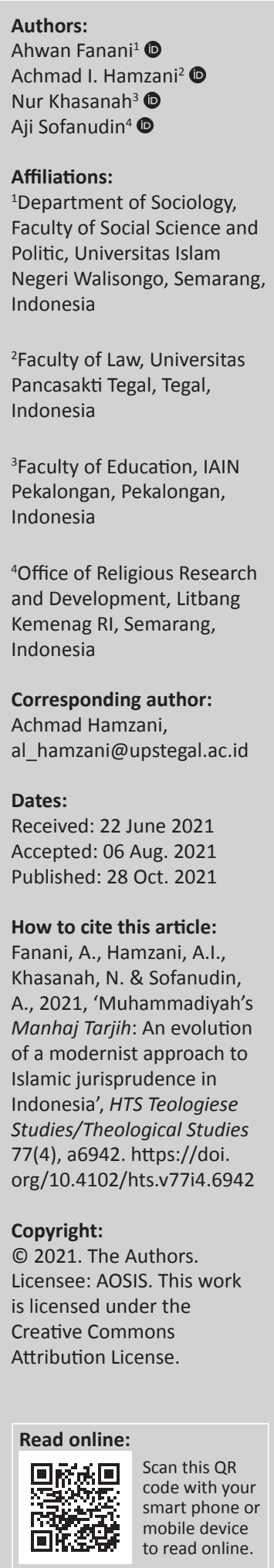

\section{Authors:}

Nur Khasanah ${ }^{3}$ (1)

Aji Sofanudin ${ }^{4}$

Faculty of Social Science and

Politic, Universitas Islam

Negeri Walisongo, Semarang,

${ }^{2}$ Faculty of Law, Universitas

Pancasakti Tegal, Tegal,

${ }^{3}$ Faculty of Education, IAIN

Pekalongan, Pekalongan,

ndonesia

${ }^{4}$ Office of Religious Research lopment, Litbang

menag RI, Semarang,

Corresponding author:

Achmad Hamzani,

Dates:

Accepted: 06 Aug. 2021

How to cite this article:

Fanani, A., Hamzani, A.I.,

Khasanah, N. \& Sofanudin,

of a modernist approach to

Islamic jurisprudence in

Indonesia', HTS Teologiese

Studies/Theological Studies

77(4), a6942. https://doi.

Copyright:

(C) 2021. The Authors.

Licensee: AOSIS. This work

is licensed under the

Creative Commons

Attribution License.

\section{Read online:}

mobile device

to read online.

\begin{abstract}
This study uses a literature study of examining the Tarjih Council of Muhammadiyah, the second largest Islamic organisation in Indonesia. Criticism is directed towards manhaj's principle which states that any classical Islamic school of law should not be embraced and, thus, breaks up from the chain of Islamic intellectuality. The critics, however, fail to cover the very idea of Muhammadiyah as an embodiment of the Islamic renewal vision. The article aims to reveal the evolution of the manhaj. The evolution will be elaborated into stages to show the development of concepts and principles in each stage. The article is based on a literature study using constructive conceptual analysis. The analysis is divided into three steps, namely analytical assessment, performative aspects, and conceptual genealogy, stressing the reflective relationship between knowledge and social reality. The study shows that the Tarjih Council's preference not to embrace any classical Islamic schools of law has developed since the establishment of the Tarjih Council. The developments of manhaj's formulation occur in three stages from 1924 until 2000. The manhaj comes up with the synthesis of textuality, rationality, and spirituality as the basic vision of Muhammadiyah's renewal idea which reflects the achievement of a modernist Islamic movement. The study, in comparison to previous research, provides a more comprehensive picture of the manhaj of Muhammadiyah as a representation of the Islamic renewal movement and shows how the manhaj comes to a synthesis that marks Muhammadiyah as a unique modernist-renewal movement.
\end{abstract}

Contribution: The study enriches the perspectives on the manhaj as the backbone of Muhammadiyah ideology and shows that Islamic modernism in Indonesia has stepped further to uncover a synthesis suitable to Indonesian society.

Keywords: manhaj tarjih; Muhammadiyah; collective ijtijad; non mazhab; modernist; Indonesia.

\section{Introduction}

The decision taken by the Tarjih Council of Muhammadiyah not to endorse any classical Islamic school of law (Anwar 2005) has been termed as a deviation of Islamic intellectual tradition (Shodiqin 2015). The term reflects the traditional understanding that Islamic orthodoxy in Sunni Islam is represented by some theological and legal schools. Muhammadiyah, on the other hand, represents Islamic renewal or modernist movements. A renewal movement, while accepting modern institutions, also relies on basic Islamic resources, the al-Qur'an and prophet traditions, and frees itself from close attachment to those theological and traditional legal schools.

Yusrizal (2017) highlighted two dimensions of Muhammadiyah's renewal: the break-up of the stagnation that the Islamic world suffered because of the penetration of the colonial powers and the refinement of Islamic teaching from polytheism, deviation, and superstition. Nashir characterised Muhammadiyah's reformation and modernisation marked by the notion that Islam contains comprehensive teachings, but has no single interpretation. To answer the contemporary dynamic of the Islamic society, Islamic interpretation is subjected to change and rational thinking (Nashir 2015:44). Noer (1996) included Muhammadiyah as a modern movement due to its acceptance of modern organisations and its support of nationalist movements. Bandarsyah (2016) emphasised the Muhammadiyah belief system and religious movement by underpinning the concept of tajdid (renewal).

The study reveals that the renewal idea shapes the nature of Muhammadiyah. Established in 1912, Muhammadiyah grew to be the biggest Islamic reformist-modernist organisation in 
Indonesia. It not only aims to purify Islamic practices in society but also to dynamise social life to prepare for modernity. Thus, it has two objectives, namely the purification and the dynamisation of religious life (Bakhtiar 2017:82). What the earlier studies fail to elaborate on is the role of the Tarjih Council, a division in Muhammadiyah which is responsible for elaborating Muhammadiyah's creeds and for issuing fatwa on behalf of the Muhammadiyah members. The Tarjih Council, therefore, is the backbone of the renewal formulation and idea in Muhammadiyah.

Although the Council has played a relevant role since 1927, the methodological construction of it is somehow slow to formulate. The spirit of returning to the al-Qur'an and the Sunnah often leads to a textualism attitude and conservatism. In 1986, the Council released The Principles of Manhaj Tarjih (the Manhaj), a scheme containing the basic idea and methodology of Muhammadiyah to deal with religious and societal issues. One important point in the principle of manhaj tarjih is a declaration that Muhammadiyah does not embrace any traditional schools of Islamic law. The manhaj, consequently, reinforces Muhammadiyah's stance in the middle of the contestations between traditional Islam and revivalist movements (Fauzi 2016).

Anwar (2005) showed that the contribution of the Tarjih Council is to create a dynamic understanding of Islam among Muhammadiyah's members. Santoso (2016) regarded the manhaj as Muhammadiyah's way of constructing Islamic purification. Setiawan (2019) considered the manhaj not only as a hermeneutic approach to Islamic law, but also as an approach to Islamic renewal. Kholidah (2021) analysed the dynamics, the pattern, and the contribution of Muhammadiyah's Tarjih on the development of Islamic law in Indonesia. She also provided a short analysis of the manhaj's formulation steps. Other scholars have also written about the manhaj, for example Amalia (2019) reflected on the method and practice of legal deduction of the Minhaj, while Fauzi (2019) wrote about the philosophical aspects of the manhaj.

This article aims to provide an overview of the evolution of manhaj tarjih and the dynamics of Muhammadiyah's religious orientation. Previous research mostly focuses on the idea behind the manhaj, rather than its evolution. The article aims to reveal the evolution of the manhaj and to show how its evolution connects to the basic renewal idea held by Muhammadiyah and the changing context. This article is based on a literature review with a descriptive and diachronic approach to obtain a picture of the evolution of manhaj tarjih.

The Muhammadiyah marked a change in the pattern of religious authority in the Muslim society of Indonesia as well as in the Islamic world. Before the establishment of the Tarjih Council, Muhammadiyah members followed the views of respected individuals, as did other Muslims. By choosing legal-rational authorities, however, Muhammadiyah, as a modernist reform movement (Pohl 2020), departs from the traditional stance of legal authority. Muhammadiyah places rational-legal authority (Tarjih Council), whose decisions are made through collective ijtihad, as the main reference for its members (Latief \& Nashir 2020:292-296).

\section{Research method}

This article is based on a qualitative research of literature. Literature research is carried out through the process of organising and sorting data into patterns, categories, and basic units of description. This data comprises books, journals, conference proceedings, and online articles. After the data is collected and categorised, the analysis is conducted through three steps, namely content analysis, discourse analysis, and interpretive analysis. This process can also be described as stating the idea of data, revealing patterns of the concepts that data contain, and elaborating the concepts to reach a conclusion.

Literature research is carried out by examining library materials or secondary data. This research includes library research because the data used are secondary in the form of documents. The data comprises both primary and secondary sources. Primary data are related to the Tarjih Council, the Manhaj Tarjih, and Muhammadiyah thoughts. Secondary data are collected by the research and study on the subjects. The data are collected through offline and online searches. The offline data are printed ones in the library or other storage, while the online data are obtained from materials, such as eBooks, journals, and conference proceedings.

The data analysis consists of the process of organising and sorting data into patterns, categories, and units of description. The analysis approach used in this research is constructive conceptual analysis. The analysis involves three steps, namely analytical assessment (what the tarjih manhaj means), performative aspects (what the Tarjih Council does), and conceptual genealogy (what the religious renewal has come to mean and how it functions). The conceptual analysis emphasises the reflective relationship between knowledge and social reality (Guzzini 2005:495-496).

\section{Findings The concept of Islamic renewal}

Islamic renewal is a term that signifies the changes introduced into the Islamic world from the 19th and 20th centuries. Islamic renewal occurred from two fronts: Islamic revivalism or fundamentalism and Islamic modernism (Kurzman 2002:4; Noer 1996). The former is an inward critique of the customary or traditional Islam deemed as having deviated from pure Islam, while the latter is in response to the penetration of Western influence in the Islamic World (Rahman 1982:43, 99). Thus, Islamic renewal is aimed at energising the Islamic world that is considered to be losing its vitality. The renewal was, therefore, launched either to 
restore Islamic society to follow the pure Islamic path or to align Islamic teaching to modernity.

The first renewal focused on the effort to purify Islamic practice as conducted by customary and traditional Islam as the deviation of true Islam (Kurzman 2002:6-7). The classical Islamic renewal (fundamentalism) criticised Islamic practice amongst Islamic society, while the contemporary Islamic renewal took an oppositional stance against Western norms and influences. Rahman called the first classical revivalism, and the second neo-revivalism (1982:136-138). The second renewal is called Islamic modernism, and is characterised by four factors: (1) the relationship between Islamic culture and sovereignty vis-a-vis European political expansion, (2) the religious institution before the advent of colonial penetration, (3) the development of Islamic education, and (4) the character of colonial policy (1982:43). The Islamic institution and culture before the coming of the Western influence are called traditionalism or customary Islam.

Kurzman (2002:4) concluded that modernism of Islam has several characteristics. Firstly, it adopts modern values consciously, such as rationality, science, constitutionalism, and human equality as the hallmarks of a modern spirit (jadid). Secondly, it employs Islamic discourse consciously and refuses to follow taqlid (unquestioning acceptance of traditional Islamic interpretation). Following Fazlur Rahman, differentiated classical Islamic modernism from neomodernism. The former focuses on education and society through the adoption of modern education and social reformation. It reinterprets Islamic sources to justify the adoption of Western institutions and thoughts. The latter focuses on contemporary issues, such as democracy, religious pluralism and gender equality.

Islamic renewal was introduced to Indonesia in the 19th century, but it grew in the early 20th century. The Paderi Movement marked the early renewal movements in Indonesia with emphasis on Islamic purification as introduced by the Wahhabites in Saudi Arabia. They focused on overcoming religious innovation, superstition, and deviation. Muhammadiyah, on the other hand, was influenced by pan-Islamist (Jamal al-Din a-Afghani), modernist (Muhammad Abduh) and reformist (Muhammad Rasyid Ridla) ideology. There are several other renewal movements in Indonesia, such as al-Irsyad, Persatuan Islam (Islamic Unity), and Sarekat Islam (Noer 1996; Padmo 2007).

\section{The working concepts in Muhammadiyah}

The working concept of Islamic renewal in Muhammadiyah is based on tajdid and tarjih. The division that formulate the concept of tajdid and tarjih in Muhammadiyah are the Tarjih and Tajdid Councils (known as Tarjih). The council was established in 1924, but the official name came from the 45th Congress 2005 in Malang. Both tajdid and tarjih could be regarded as the worldview of Muhammadiyah as a representation of the renewal movement.
Tajdid is defined as a process of returning to Islamic teachings to revitalise Islamic society from stagnation by opening the door of ijtihad (Hasyim 1990:13) and restoring the purity of Islam (Shobron, Hidayat \& Shibahiya 2010:2-3). Tajdid is a keyword of Muhammadiyah's religious orientation. Following alAfghani, Abduh, and Ridla, the religious orientation of Muhammadiyah is to return to the basic teachings of the alQur'an and Prophet Traditions (Sunnah) as well as to reconcile traditional Islamic education with modern education (Shabir \& Susilo 2019). The reform movement launched by Muhammadiyah operates under the tajdid concept. Tajdid is a fundamental characteristic of Muhammadiyah as the Modernists Reform Movement because the purification of Islamic teachings and the dynamisation (modernisation) of life as a main concern of Muhammadiyah are coined by the concept tajdid (Bakhtiar 2017).

The second keyword of Muhammadiyah is tarjih. The term tarjih, in classical Islamic jurisprudence, means choosing conflicting arguments and conflicting opinions (Anwar 2018:6; Balfaqih 2017). A modernist scholar, Abdul Hamid Hakim, defined tarjih as the process of selecting contradicting prophet traditions by considering the chain of reporters, content, and external factors (Hakim n.d.). The term, however, has a different meaning in Muhammadiyah. Anwar said that the term tarjih developed from ijtihad theory, but later it became synonymous with that of ijtihad (Anwar 2005). Currently, the terms istinbath, ijtihad, and tarjih are used interchangeably to designate the mechanism for conducting legal deduction (istinbath) with any legal method known in Islamic jurisprudence.

The process of legal deduction in the Tarjih Council is conducted through collective ijtihad (legal inference) by Muhammadiyah's scholars and leaders. The Tarjih Council conducted ijtihad collectively either to revisit old opinions of Islamic classical schools or to conduct new ijtihad. The idea is not new because Yusuf Al-Qardlawi (1996), a Qatar cleric, proposed the two models of the Islamic legal deductions. The collective legal inference is a choice of the Tarjih Council which provides Muhammadiyah's scholars with legitimacy to deal with the cases related to Islamic law without any obligation to follow classical authorities.

\section{The Manhaj as a dynamic concept}

Manhaj tarjih refers to the deduction method or thinking approach employed by the Tarjih Council in resolving religious and Islamic law problems. The manhaj got wider recognition in 1986 when the Central Tarjih Council released the 'Principles of Manhaj Tarjih'. Anwar (2005), the chairman of the Tarjih Council, defined the manhaj as 'a system that contains a set of insights, sources, approaches and certain technical procedures (methods) as guidance in tarjih activities'. The definition represented a recent understanding of the manhaj among Muhammadiyah's clerics. The National Conference of the Tarjih Council 2000 included the four aspects, namely insights, sources, approaches and methods, integral elements of the manhaj. In sum, the manhaj 
comprised the perspective and the methodology used in tarjih activities.

The manhaj represents the methodological aspect in legal deduction as well as religious understanding. It reflects the basic constructs of Islamic jurisprudence (ushul figh) that are usually discussed on law, sources of law, deduction methods, and authority to do the deduction process (Ghazali 2000). The manhaj also contains new approaches, known as bayani (textual), burhani (logical) and irfani (spiritual) simultaneously. The approaches have been received into the Muhammadiyah document called The Guidance of Islamic Life for Muhammadiyah Members (Head of the Muhammadiyah Center 2018a, b). The reception of the three approaches underpins Muhammadiyah's way of dealing with religious and social challenges.

The change that the Tarjih Council introduced into the manhaj represents the way in which Muhammadiyah is taking its position amidst internal obstacles and external challenges. Haedar Nashir (2000), the General Chairman of Muhammadiyah, regards the internal problems of Muhammadiyah as coming from the lack of loyalty, understanding, and ties of Muhammadiyah members to their ideology so that they look for enlightenment from other movements. The external challenges include new ideologies that undermine Muhammadiyah's modernists-reformist vision. The new ideologies, which Nashir (2000) pointed out, are neo-modernism, neo-revivalism, and neo-traditionalism. Muhammadiyah has lost its young members since the late 1980s because of the migration to the new movements. The manhaj is a safeguard for Muhammadiyah to protect its appeal and position in the new socio-religious changing environment.

The manhaj was not formed as it is now, rather it developed gradually. The formulation of the minhas is a long drawn process because of the practical and social service orientation that Muhammadiyah has and the prevalent textualism that many Muhammadiyah clerics embrace. Consequently, the formulation of its conceptual aspects is left behind. The Tarjih Council, however, manages to formulate the basic principles of the manhaj through several stages. The first stage is the conceptual formulation directed to answer the religious polemics among Muhammadiyah's members. The second is the formulation of basic principles of the manhaj in 1986. The last is the formulation of the complete map of Manhaj al-Tarjih in 2000 which contains basic philosophy, approaches, methods, and techniques for conducting legal deduction as well as for performing religious renewal (tajdid).

\section{First stage: Initial formulation}

The Tarjih Council was established in 1927 to provide its members with formal views and the ideology behind the formulation of the organisation. Since its establishment, the Council facilitated a forum for Muhammadiyah's scholars and clerics to resolve disputes amongst its members, based on the reference to the al-Quran and Sunnah, the rejection of religious imitation (taqlid) (Kulsum \& Alfian 2006). Mas Mansur, who later became the chairman of Muhammadiyah, was the initiator of the Tarjih Council. He formulated 'The Twelve Steps of Muhammadiyah 1938-1940' (Hasyim 1990), one of which was to broaden the understanding of religion and to purify religious understanding amongst Indonesian society.

Mas Mansur also contributed to the formulation of the early creeds of Muhammadiyah in Masalah Lima (The Five Issues) in 1935. The Masalah Lima laid down Muhammadiyah's idea of the purification and the dynamisation of the Muslim life (Hasyim 1990). The Masalah Lima was then included in Himpunan Putusan Tarjih (The Compilation of Tarjih Decisions); the first compilation of Muhammadiyah's that answers to several religious issues (Kulsum \& Alfian 2006). It comprises the answers on: what is religion, what are worldly affairs, the meaning of worship, the sabilillah (the work in God's path), and religious interpretation (ijtihad).

\section{Second stage: The principles of the Manhaj}

The second stage of manhaj formulation was in 1986, when the Council issued 18 principles of Manhaj Tarjih (Abdurrahman 2004). The formulation contains Muhammadiyah's position on several issues, such as the non-affiliative position of classical schools of Islamic law and more elaborated principles of religious understanding according to Muhammadiyah. On legal deduction, the principles of Manhaj highlight the alQuran and Sunnah as the only sources of Islamic teachings, while also recognising other argumentative proofs, such as the consensus of the Prophet's companions, the use of analogical deduction (qiyas), and considering public good. The principles of Manhaj state that 'the finding of legal reason can be employed to understand the contents of Qur'anic and prophetic arguments as long as it is in accordance to the objectives of the shari'a' (Hidayat 2007).

The inclusion of qiyas into the Manhaj broadens the horizon of legal deduction not to be confined to textual deduction, but also to use analogical deduction in private and public matters. The principles, therefore, recognised three methods of legal deduction: istislahi (public goodbased deduction), bayani (textual-based deduction), and qiyasi (analogical-based deduction), as put forward by Muhammad Ma'ruf al-Dawalibi in 1965 (Abdurrahman 2004). Meanwhile, urf' (social habit) is not explicitly stated as a method in the principles of the manhaj, but it was taken as a legitimate argument by the Central Java Board of Muhammadiyah in 1986 (Majlis Tarjih and Tajdid PW Muhammadiyah 2010).

In summary, the principles reinforce the position of Muhammadiyah as a reform movement. The non-affiliative stance to classical schools of law and theology that reinforced the rejection of the uncritical acceptance of religious opinions of traditional authorities (taqlid). The stance embodies Muhammadiyah's attitude toward free religious interpretations conducted through collective ijtihad. 


\section{Third stage: The Manhaj of $\mathbf{2 0 0 0}$}

The last formulation of the Manhaj Tarjih was achieved at the 24th Tarjih National Conference 2000, followed by the 25th Tarjih National Conference in Jakarta in the same year. The 2000 Manhaj Tarjih was the response of Muhammadiyah to external challenges as well as to internal problems. Since late 1998, Indonesia saw the rise of the middle-class. Traditionally, Muhammadiyah attracts the middle-class, but they now searched for spiritual and Sufistic enlightenment. Unfortunately, Muhammadiyah's idea of renewal tends to give more attention to modernity and religious purification than Sufistic spirituality (Nashir 2020).

The 24th Tarjih National Conference introduced bayani, burhani and irfani, having been popularised by Muhammad Abed Al-Jabiri (1991). The bayani approach rests on the textual understanding of the al-Quran and prophetic traditions, the burhani rests on reason and science, and the irfani emphasises heart and religious feeling. Both bayani and burhani approaches did not lead to any objection, but irfani approach had sparked a heated debate among Muhammadiyah scholars before it was approved as an approach for tajdid and tarjih. This was because irfani stems from mysticism deemed incompatible with the Islamic purification endorsed by Muhammadiyah. Finally, Muhammadiyah scholars reinterpreted the irfani approach to be suitable with Muhammadiyah's basic thoughts by closely linking it to the approaches of bayani and burhani.

The Manhaj, then, systematises the structure of the religious interpretation of Muhammadiyah. It contains a basic definition of important terms and states the sources of law and teachings. The Manjah provides more clear concepts of ijtihad methods, approaches, and techniques. The ijtihad includes hermeneutic, sociological, historical, and anthropological approaches. It elaborates in detail the principles of Manhaj of 1986. It also reaffirms the mechanism for resolving the contradicting significance of texts and the rules of evaluating prophetic traditions.

The Manhaj Tarjih 2000 provides a new orientation of tajdid inside Muhammadiyah. It introduces irfani, a kind of spiritual orientation, to enrich textual and rational tendencies among Muhammadiyah's members. Haedar Nashir regarded the reception of the irfani as an exit-way to respond to new religious issues faced by Muhammadiyah and to endorse spirituality as an integral part of Muhammadiyah's understanding of Islam (Anwar 2018). The Manhaj acted as an ideology for Muhammadiyah as a religious renewal movement.

\section{The Manhaj between concept and reality}

Manhaj Tarjih of Muhammadiyah is the formulation of the renewal idea held by Muhammadiyah. The religious reforms carried out by Muhammadiyah contain two elements, namely the purification of the Islamic teachings and the dynamics of social life. The reforms then represent the synthesis of Islamic modernism and revivalism. Manhaj
Tarjih evolved because Muhammadiyah was initially established to improve education, health, and social affairs and was not originally intended as a religious sect.

Muhammadiyah's religious renewal is rooted in the thinking of the Egyptian modernists, Muhammad Abduh and Muhammad Rasyid Ridla. It combines the elements of modernity and open interpretation of the sources of Islamic teachings and therefore it contains both the modern and salafistic tenets. Muhammadiyah endorses the open ijtihad by referring directly to the Islamic sources (al-Quran and Sunnah) and accepting modern influences. This idea is the antithesis of the traditional Islamic view that seeks to preserve religious thoughts and structures existing since the founding of the Islamic schools of law and theology. Therefore, Muhammadiyah's choice not to endorse classical schools of law and theology reflects the idea of religious renewal that it holds.

The Muhammadiyah's idea of religious renewal was not stagnant, it evolved. The Tarjih Council is the division that is responsible for formulating the ideology of Muhammadiyah. Initially formed to answer the religious problems, the Tarjih Council also provides Muhammadiyah with a set of beliefs and religious orientations to deal with internal problems as well as external challenges, especially the dynamics of the Indonesian society.

The Manhaj Tarjih evolved from a simple guide to interacting with Islamic sources to more sophisticated and evolved concepts. The Manhaj was adapted and updated to respond to new needs and challenges. The principle of the Manhaj 1986, for instance, set three methods of legal interpretation in accordance with the new development of ijtihad methods in Islamic law. The attitude of Muhammadiyah toward spirituality has also shifted. The rise of Islamic revivalism in the 1970s and urban Sufism attracted the interest of the urban community, traditionally the segment of Muhammadiyah. Under the challenge, the Manhaj 2000 approved irfani as a legitimate religious approach along with bayani and burhani. Althoughstruggling toredefineirfani to suitMuhammadiyah's reform character, the Manhaj evolved to cope with new religious challenges.

The evolution of the Manhaj Tarjih not only shows the dynamic nature of Muhammadiyah thinking, but it also raises several problems. Firstly, the new concept takes a long time to be fully understood and implemented by Muhammadiyah's scholars. Secondly, the Manhaj develops so dynamically and conceptually that Muhammadiyah's members struggle to define it. In summary, the evolution of Muhammadiyah's religious thought in addition to reflecting on the idea of religious renewal, also places Muhammadiyah in the middle of a struggle to make it work.

\section{Conclusion}

Manhaj Tarjih is the backbone of Muhammadiyah that upholds its religious thinking and ideology amidst the socio-religious challenges taking place in Indonesia. Initially, Muhammadiyah 
offered the modernist reform idea to renew the existing religious currents in the Indonesian society through the formulation of Muhammadiyah's understanding of the concepts of religion, the world, and analogical deduction from religious text. Since the 1970s, the wave of revivalist movements, known as transnational movements, had entered Indonesian atmospheres and brought in a new way of Islamic thinking and movements. Besides, urban society that traditionally becomes Muhammadiyah's segment turns to be more devoted. The function of the religious renewal of Muhammadiyah was internally questioned. The Tarjih Council then reformulated the Manhaj so that it came up with the principle of manhaj in 1986, and set a more comprehensive religious approach into the Manhaj 2000.

Manhaj Tarjih is an anchor of Muhammadiyah to stay on its track while being flexible in accepting changes. Manhaj Tarjih does not come into formulation directly, rather it undergoes a gradual process of formulation. The track of Muhammadiyah is a reformist-modernist movement that supports the purification of religious life and the dynamisation of social life through the adaptation of modernity. The manhaj, therefore, revolves around the two notions while it develops new approaches to deal with social and religious changes. The dynamics of manhaj lead to the unique response of Muhammadiyah to the ongoing social changes, and this makes it different from the other renewal movements.

The Tarjih Council is the forefront board to defend Muhammadiyah's ideology. The Council struggles to define Islamic renewal to provide Muhammadiyah with a set of religious orientations and approaches. The Council has come up with a more sophisticated formulation in 2000, but it also raises the challenge to make it work. Consequently, Muhammadiyah's religious thought will always evolve, but the evolution also introduces new challenges for the right understanding and implementation.

\section{Acknowledgements}

The authors would like to express their gratitude to the Faculty of Social Science and Politic, Universitas Islam Negeri Walisongo, which provided funding for this research.

\section{Competing interests}

The authors declare that they have no financial or personal relationships that may have inappropriately influenced them in writing this article.

\section{Authors' contributions}

All authors contributed equally to this research article. Each was involved in the preparation of research design, data collection, analysis and article writing.

\section{Ethical considerations}

This article follows all ethical standards for research without direct contact with human or animal subjects.

\section{Funding information}

This research received no specific grant from any funding agency in the public, commercial, or not-for-profit sectors.

\section{Data availability}

Data sharing is not applicable to this article as no new data were created or analysed in this study.

\section{Disclaimer}

The views and opinions expressed in this article are those of the authors and do not necessarily reflect the official policy or position of any affiliated agency of the authors.

\section{References}

Abdurrahman, A., 2004, Manhaj Tarjih Muhammadiyah, Methodologi dan Aplikasi, Pustaka Pelajar, Yogyakarta.

Al-Jabiri, M.A., 1991, Bunyah al-'Aql al-'Arabi, al-Markaz al-Tsaqafî al-'Arabî, Maroko.

Al-Qardlawi, Y., 1996, al-ljtihad fi al-Syariah al-Islamiyyah Ma'a Nadzarat Tahliliyah fi al-ljtihad al-Mu'ashir, Dar al-Qalam, Kairo.

Amalia, H., 2019, 'Muhammadiyah: Metode dan Praktik Berijtihad', Mu'addib 9(2), 119-130. https://doi.org/10.24269/muaddib.v1i2.1535

Anwar, S., 2005, 'Fatwa, purification and synamization: A study of Tarjih in Muhammadiyah', Islamic Law and Society 12(1), 27-44. https://doi. org/10.1163/1568519053123894

Anwar, S., 2018, Manhaj Tarjih Muhammadiyah, Panitia Musyawarah Nasional Tarjih, Yogyakarta.

Bakhtiar, 2017, 'Corak Pemikiran Hukum Majelis Tarjih Muhammadiyah', Al-Qalb 9(2), 77-91.

Balfaqih, A.B.H., 2017, Mathlab al-lqadz fi al-Kalam ala Syai' min Ghurar al-Alfadz, Dar al-Dliya, Kuwait.

Bandarsyah, D., 2016, 'Dinamika Tajdid dalam Dakwah Muhammadiyah', History 2(2), 67-74. https://doi.org/10.24127/hj.v4i2.534

Fauzi, N.A.F., 2016, 'The Tajdid Movement of Muhammadiyah in Aceh: Negotiating identity between Salafism and Modernism', Jurnal Tarjih 13(2), 155-170.

Fauzi, N.A.F., 2019, 'Muhammadiya's new Figh reasoning: Constructing a Holistic Islamic law paradigm', Afkaruna 15(1), 32-54. https://doi.org/10.18196/ AlIJIS.2019.0094.32-54

Ghazali, A.H., 2000, Al-Mustashfa fi Ilm al-Ushul, Dar al-Kutub al-IImiyyah, Beirut.

Guzzini, S., 2005, 'The concept of power: A constructivist analysis', Millenium - Jorna of International Studies 33(3), 495-521. https://doi.org/10.1177/0305829805033 0031301

Hakim, A.H., n.d., Al-Bayan, Pustaka Sa'diyah Putra, Jakarta.

Hasyim, U., 1990, Muhammadiyah, Jalan Lurus dalam Tajdid, Dakwah, Kaderisasi dan Pendidikan: Kritik dan Terapinya, PT Bina Ilmu, Surabaya.

Head of the Muhammadiyah Center, 2018a, Himpunan Putusan Tarjih 3, Suara Muhammadiyah, Yogyakarta.

Head of the Muhammadiyah Center, 2018b, Pedoman Hidup Islami Warga Muhammadiyah, Suara Muhammadiyah, Yogyakarta.

Hidayat, S., 2007, 'Konstruk Metodologi Pemikiran IUslam di Muhammadiyah', Profetika 9(1), 99-125.

Kholidah, 2021, 'Dynamics of Tarjih Muhammadiyah and its contribution on the development of Islamic law in Indonesia', International Seminar of Islamic Studies 2(1), 760-766

Kulsum, U. \& Alfian, I., 2006, 'Majlis Tarjih Muhammadiyah pada Masa Pemerintahan Hindia Belanda 1927-1942: Kajian Pemikiran', HUMANIKA 19(3), 75-87.

Kurzman, C., 2002, Modernist Islam, 1840-1940: A sourcebook, Oxford University Press, Oxford.

Latief, H. \& Nashir, H., 2020, 'Local dynamics and global engagements of the Islamic modernist movement on contemporary Indonesia: The case of Muhammadiyah (2000-2020)', Journal of Current Southeast Asia Affairs 39(2), 290-309. https:// doi.org/10.1177/1868103420910514

Muhammadiyah Central Board of Tarjih and Tajdid, 2010, Himpunan Putusan Tarjih Jawa Tengah, Majlis Tarjih dan Tajdid Pimpinan Wilayah Jawa Tengah dan Universitas Muhammadiyah Surakarta, Surakarta.

Nashir, H., 2000, Revitalisasi Gerakan Muhammadiyah, BIGRAF Publishing, Yogyakarta.

Nashir, H., 2015, Understanding the ideology of Muhammadiyah, Muhammadiyah University Press, Surakarta. 
Noer, D., 1996, Gerakan Moderen Islam di Indonesia 1900-1942, LP3ES, Jakarta.

Padmo, S., 2007, 'Indonesian Islamic renewal movement from time to time: An introduction', Humaniora 19(2), 151-160.

Pohl, F., 2012, 'The Muhammadiyah: A Muslim modernist organization in contemporary Indonesia', in M.D. Palmer \& S.M. Burgess (eds.), The WileyBlackwell companion to religion and social justice, pp. 241-255, Blackwell Publishing, Oxford.

Rahman, F., 1982, Islam and modernitry: Transformation of an intellectual tradition University of Chicago Press, Chicago, IL.

Santoso, M.A.F., 2016, 'Internasionalisasi Konsep Purifikasi dalam Manhaj Tarjih Muhammadiyah', Jurnal Muhammadiyah Studies 1(1), 30-43. https://doi. org/10.22219/jms.v1i1.11407
Setiawan, B.A., 2019, 'Manhaj Tarjih dan Tajdid: Asas Pengembangan Pemikiran dalam Muhammadiyah', Tarlim 2(1), 35-42. https://doi.org/10.32528/tarlim.v2i1.2068

Shabir, M. \& Susilo, S., 2019, 'Muhammad Abduh's thought on Muhammadiyah educational modernism: Tracing the influence in its early development', Qudus International Journal of Islamic Studies 6(2), 128-159. https://doi.org/10.21043/ qijis.v6i2.3813

Shobron, S., Hidayat, S. \& Shibahiya, M., 2010, Studi Kemuhammdiyahan: Kajian Historis, Ideologis dan Organisasi, Lembaga Pengembangan Ilmu-Ilmu Dasar Universitas Muhammadiyah Surakarta, Surakarta.

Shodiqin, M.A., 2015, Muhammadiyah itu NU: Dokumen Fikih yang Terlupakan, Penerbit Noura Books, Jakarta.

Yusrizal, 2017, 'Corak Pembaharuan Pemikiran Syari'ah Muhammadiyah', Menara Ekonomi 3(5), 144-153. 